811.163.41'35:81'373.2

811.163.41'342.623

https://doi.org/10.18485/sj.2021.26.1.30

ГОРАН Н. ЗЕЉИТ *

Универзитет у Београду

Учитељски факултет
Оригинални научни рад

Примљен: 13. 10. 2020.

Прихваћен: 12. 1. 2021.

\title{
ПРАВОПИСНИ ИЗУЗЕЦИ ОД АЛТЕРНАЦИЈА ПО ЗВУЧНОСТИ НА ПРИМЕРУ АДАПТИРАНЕ СТРАНЕ ОНОМАСТИКЕ
}

На примеру адаптиране ономастике из страних језика (посебно енглеског, руског и немачког), анализирају се правописни изузеци од алтернација по звучности. Овај правописни проблем сагледан је кроз анализу нормативних приручника почев од Белићевог правописа из 1923. године и његових наредних издања, до Матичиних издања закључно са актуелним из 2010, те Дешићевим (из 2015) и Симићевим (из 2016) нормативним приручником. Примери су ексцерпирани из новинских издања и преводне књижевности.

Кључне речи: правопис српског језика, алтернација по звучности, правописни изузеци, адаптација стране лексике, ономастика.

\section{1. УВОД}

Алтернација по звучности је једна од најчешћих алтернација у српском језику. У правописној норми она је фонолошки обележена, али са извесним одступањима.

Уобичајено је, још из Вуковог времена, да се као примарно истиче да до алтернације $\partial: m$ неће доћи ако је сугл. $\partial$ испред безвучних сугласника $c$ и $u$. Вук Караџић у Рјечнику (Караџић 1818) наводи примере попут господски (1818:

*goran.zeljic@uf.bg.ac.rs 
205) и градски (206), те надскакивање, надскакивати (301), одсвакле, одсвакуд, одседнути, одселити (се), одсути, одметати (335), подсад, подседлииа, подсећи, подсецање, подсмевати се (376) и сл., али и пример придева љуцики (1818: 380). Потврду за облик љуицки налазимо и у Даници за 1829. годину: „То је наука, која ум љуцки готово превазилази” (1829: 1).

Од тада, делом изузимајући Белићеве правописне приручнике, у српском језику овај изузетак је део стандарда.

\section{2. НОРМИРАЬЕ ПРАВОПИСНИХ ИЗУЗЕТАКА ОД АЛТЕРНАЦИЈЕ ПО ЗВУЧНОСТИ}

1. Управо овај изузетак од алтернације по звучности унео је још С. Чутурило у свој приручник са примерима градски, брдски, господски, људски, одслужсти, одселити, надсмијати (Чутурило 1984: 13).

2. С друге стране, Белић у издању из 1923. критикује ово Вуково решење јер је оно довело, о чему и данас сведочимо, до тога да „под утицајем ових отступања почиње се и другде остављати неизмењен звучни сугласник пред муклим: пише се: подпуковник, подпредседник и т. д.” (Белић 1923a: 81). На следећој страници Белић, уз залагање за доследну алтернацију по звучности, ипак оставља могућност и решења без те алтернације у примеру људски уз облик љутски, али додаје да би ипак „ваљало и ту што пре остати са једним рационалним писањем - $m c^{\prime \prime}(83)^{1}$. На исти начин у правописном речнику приручника из 1923. налазимо топоним Охритско језеро и са дублетним завршетком -идско датим у загради у коме није дошло до алтернације по звучности (235). Већ у другом издању, оном из 1930. године, Белић коригује свој став да је потребно доследно вршити алтернације по звучности и то тако што (прихватајући Караџићеве разлоге) издваја придевске и именичке изведенице на -ски и -ство типа људски и судство да би се избегло развијање графеме $u$ (не љуицки), док би се алтернација $\partial: m$ јављала у префиксалним сложеницама попут претседавати, отсећи, отметати и сл. (Белић 1930: 55-56). Наравно, ово решење усклађено је са Правописним упутством из 1929. године. Од тог приручника из 1930. установљено је обавезно поглавље посвећено транскрипцији туђих (по Белићу) односно страних речи, у коме су правила о гласовним алтернацијама била поткрепљена примерима али и огрешењима. Тако Белић наводи примере који су и данас тако нормирани попут Дрезден (нем. Dresden), Хабзбург (нем. Habsburg), Рендген (нем. Röntgen) (Белић 1930: $89)$ примењујући правило о „мењању сугласника по звучности”. У издању из

${ }^{1}$ Детаљније в. Белић 1923б: 206-218. 
1950. додати су примери Глатков (1950: 113; рус. Гладков), Велигден (115; буг. Великден), али и Дбилиси (114; укр. Тбилиси).

3. Правописом из 1960. године у издању Матице српске и Матице хрватске враћамо се доследно вуковској традицији и правилу да испред безвучних сугласника $c$ и $u$ неће доћи до алтернација $\partial: m$ и $\hbar: \hbar$. Овај изузетак илустрован је великим бројем примера, како префиксалним сложеницама попут одступити, одшетати, одштампати, тако и изведеницама градски, људство, водство и сл. Први пут међу примерима налазимо и позајмљенице попут субполаран, јурисдикиија, адхерентан, постдипломски, али и предтурски и подтекст да се не би изгубила веза са њиховим значењем (64), те властите именице и од њих изведене придеве Вашингтон, вашингтонски, Хабсбурговци, хабсбурики, Рентген (али рендген-апарат), Мусоргски ${ }^{2}$. Коначно, трећу групу изузетака од алтернација по звучности илуструју примери властитих имена Мидхат, Едхем, Субхија, односно Кадчић (разлика Качић), Забрдаи (у промени Забрдиа, Забрдиу итд., а не Забриа, Забриу итд.) и Бргудаи, Бргудия, Бргудиу итд. (место у Истри) (1960: 64). Као и у Белићевим правописним приручницима, сада детаљније, обрађено је транскрибовање страних речи, па и ту налазимо примере попут Дрезден (стр. 145, нем. Dresden), Блекберн (152, енгл. Blackburn), Мегбет (153, енгл. Macbet), Штутгарт (154, нем. Stuttgart), Бизмарк (154, нем. Bismark), Потхрупски (160, слов. Podhrasky), Слаткович (160, слов. Sladkovic), Безбротко 162, (рус. Безбродко), Мерешковски (162, рус. Мережковски), Глатков (163, рус. Гладков), Рутченко (162, укр. Рудченко), Расиветников (162, буг. Разиветников), Лопковице (162, чеш. Lobkovice), Хроматка (162, чеш. Hromadka), док су као изузеци наведени Чадия (160, слов. С̆adca), Подтатрански (160, слов. Podtatransky), због алтернације т:ø која би уследила после алтерн. д:m, те Мусоргски (163, рус. Мусоргский) и у правописном речнику адхеренција (176), Јосипдол (360), јурисдикција (361).

4. У приручницима из 1993. године - Матичином (Пешикан и др.) и Симић и др. - поред сад већ уобичајених твореница страним формантом попут нузспеиијалност, субпериодизаиија, адхезија, јурисдикиија, допуштају се изузеци од алтернације по звучности (уз упрошћавање сугл. група) у ономастици са примерима Забрдаи, Забрдия (ум. Забриа), Подхум (и Потхум), те Врхбосна (П93: 145), односно Вукдраговић (и Вугдраговић), Грубковић (и Групковић), Драгче (и Дракче), Подхум, те у страним именима „обавезно је бележити оно што налаже сродност облика: Велингтон, Монтгомери, Мусоргски, Рентген, Вашингтон, Витебск, Регенсбург итд." (Симић и др. 1993: 77)³, затим Гладки (од рус. Гладкий), Гудков (рус. Гудков), Мусоргски (рус. Мусоргский), Рижков (рус. Рижков) (326), Рентген (нем. Röntgen), Аугсбург (нем. Augsburg),

\footnotetext{
${ }^{2}$ Исто у Стевановић 1986: 110.

${ }^{3}$ Исто у Симић 2016: 73.
} 
Дресден (нем. Dresden) алтернације по звучности овде је оправдано и онда када постоји свест о „смисаоној двочланости речи” која често „повлачи са собом и рашчлањен, паузалан изговор, при коме се поред главног акцента у некој речи испољава и секундарна споредна наглашеност, а у неким случајевима остварује се и јасан двојни акценат" (П93: 145).

5. Најновији правописни приручници, они из двехиљадитих, донели су делимично разјашњење постојања изузетака од алтернације по звучности. Наиме, у Матичином приручнику из 2010. алтернација по звучности вршила би се доклегод би те „замене повукле и замену других сугласника” (П2010: 38), па се као нормативни дају између осталих примери Глазгов, Дрезден, Визбаден, Хабзбург, Јоханезбург, Регензбург, Ружди, Ришков, Голупков и сл., док би одступања била у примерима који су ушли „у нашу културу у другом облику или ако би и после извршеног једначења остала сугл. група страна српском језику, као нпр.: Мусоргски, Рјажски, Гудиов, Дјадченко (једначењем би настале сугл. групе -кск-, -иск-, -тu-, тч-)" или да би се избегло удаљавање од основне речи или да би се поштовала традиција, те су дати примери попут Подхум, Подхрастови, Градаи - Градиа, Бургудаи - Бургудиа или у презименима „која немају карактер дублета” попут Вугдраговић - Вукдраговић, Дапчевић-Дабчевић, Качић-Кадчић (П2010: 38; в. и Дешић 2015: 39 и 145).

6. На основу анализираних правописних приручника, представљене примере којима се илуструју изузеци од алтернације по звучности можемо разврстати у две групе и то а) примере опште или терминолошке лексике и б) ономастике. Изузеци од алтернације по звучности у обема групама објашњавају се а) избегавањем даљих алтернација (нпр. људски > љутски > љуияки; субполаран > супполаран > суполаран; Градаи $>$ Градиа $>$ Гратия $>$ Граца и сл.) или б) устаљеношћу (традицијом) у пракси (нпр. Редфорд - презиме глумца) или в) неудаљавањем од основне речи (нпр. Подхум, адхерентан и сл.). Имајући то у виду, анализирали смо примере у пракси, а због њихове бројности, у првом плану су нам примери из ономастике и то они преузети из других језика, делимично или потпуно адаптирани у нашем систему.

7. У литератури је о овим правилима о изузецима од алтернација доста писано (нпр. Симић 1991; Стакић 2010; Шипка 2011). Бавећи се питањима српске (српскохрватске) ортографије и односа Вукових настављача у савременом добу, Радоје Симић констатује да је наша правописна норма оптерећена „баластом компликованих правила која се у пракси често не поштују, нити се могу доследно примењивати" (Симић 1991: 351). Тако се Симић у вези са алтернацијом по звучности залаже за етимолошки принцип у писању страних властитих имена са, дакле, ослањањем на изворни облик попут $B u$ -

${ }^{4}$ У фусноти овог приручника додато је да је по традицији и Дрезден (345). 
тебск, Јакобсон, укључујући и присвојне придеве изведене од тих именица суфиксима -ов/-ев и -ин попут Јакобсонов те именичких изведеница као што су Аугсбуржанин, Вашингтонаи (Симић 1991: 143). Међутим, код придевских изведеница на -ски (-чки, -ики), које се пишу малим почетним словом, Симић даје предност писању са алтернацијом по звучности (фонографско писање): хабзбуршки, аугзбуршлки, вашинктонски и сл. (Исто). Наведена студија била је потом основа за израду неколико правописних приручника у којима је Р. Симић (ко)аутор (Симић 1993; Симић ред. 1998; итд.). Осврт на предложена правописна правила о изузецима од алтернације по звучности у актуелном Матичином приручнику (2010) дао је М. Шипка (Шипка 2011), који, у делу посвећеном властитим именима страног порекла наводи она властита имена „која се нису адаптирала у нашем језику, па чувају свој изворни правописни лик” попут Вашингтон (вашингтонски), Гибсон, Бангкок, Хонгконг, Јангие, Редфорд, Тбилиси, Абхазија и сл. (Шипка 2011: 81), не наводећи узроке те неадаптираности и евентуалне могућности њихове накнадне адаптације. С друге стране, код презимена попут Грабчановић, Зубчевић, Дабчевић и сл., Шипка разлоге изостанка алтернације по звучности види у постојању ликова са извршеном алтернацијом (Грапчановић, Зупчевић, Дапчевић). У примерима властитих именица типа Градац, попут П2010, Шипка као нормативно прихватљиве даје облике Градияа, Градиу, јер би алтернација по звучности довела до алтернације т:ø (губљења сугл.) и облика Граца, Гращу и сл., па бисмо на тај начин добили облике властите именице Граи (град у Аустрији) (Шипка 2011: 82).

8. Пошто је реч о страним личним именима и географским називима, утицај на правописна правила и решења имају и правила о транскрипцији и транслитерацији страних речи. И ту је литература обимна, поготово имајући у виду велики број језика из којих се дати називи преузимају и адаптирају. Видели смо да је и у правописним приручницима доста пажње посвећено управо преношењу тих имена у српски језик. У подробној анализи тих решења, Р. Маројевић, наравно на примеру руског језика, а у осврту на нека Белићева решења дата у његовом правописном приручнику, указује на вишеслојност у адаптацији руских антропонима и топонима (Маројевић 1988). У фонолошкој адаптацији руских имена А. Менац предлаже да се асимилације по звучности и месту творбе, по угледу на руски језик, не врше (нпр. Гладков, Бережков и сл.) (Менац 1971/72: 107). Супротно, други слависта, Богдан Терзић, оправдава алтернације по звучности у примерима Рипкин $(<$ Рибкин), Збитьев (< Сбитњев) и Потколзин (< Подколзин), јер су подстакнуте „подударношћу словенских морфема у ова два језика (упор. наше рипче)" (Ћупић и др., 1996: 205).

9. На примеру енглеског језика, у оквиру дела посвећеног правописним специфичностима Прћић (Прћић 2004: 19) наводи, сходно П93, да се „озвучавање и обезвучавање, иако може постојати у изговору, не приказује", те даје 
различите примере - попут Anдајк и Ещби - са самогласником у иницијалној позицији у речи испред групе у којој неће доћи до алтернације по звучности, те Бедфорд и Арлингтон (односно Редфорд и Карингтон у Прћић 1998: ХXX). ${ }^{5}$

\section{3. АКТУЕЛНА ПРАКСА}

1. У раду смо анализирали (не)адаптиране примере из ономастике. У брзом протоку информација, у бујању издавачке делатности, језички стручњаци не стигну да нормирају, односно (у нашем случају) адаптирају страну ономастику. Остављају се решења која је адаптирао преводилац сходно своме образовању, које је понекад мањкаво када је реч о српском језику и познавању његове стандарднојезичке норме. Врло често, до морфонолошке адаптације доћи ће накнадно, чиме се одмах нарушава једно од нормативних постулата истакнутих у нашем тексту, а то је устаљеност, традиција ${ }^{6}$. Два смо примера издвојили.

2. Први је презиме британског писца индијског порекла Салмана Руждија (енгл. Salman Rushdie), чија су прва дела потписана презименом Рушди без алтернације ш:ж, нпр. у делима Деца поноћи (1989) и Сатански стихови (1991), али и са алтерн. ш:ж, у делима Срамота (2002), Гримус (2004) и Кловн Шалимар (2007).

Матичин правопис из 2010. у овом презимену препоручује алтернацију ш:ж, па су иста дела имала облик презимена са алтернацијом $ш: ж$ и то у романима Деца поноћи (2013) и Сатански стихови (2019).

3. Други пример је супротан по смеру. Наиме, презиме америчког песника и писца Алена Гинзберга, са алтерн. с:з (енгл. Allen Ginsberg) нашло се на првим делима штампаним на српском (српскохрватском) језику (Гинзберг 1983а и $1983 б$ - Урлик ума, изабране песме; Хидрогенски иубокс: изабране песме), а без те алтернације у издању из 2016. године (Изабрана писма).

4. Без алтернације по звучности јављају се и презимена више аутора чија су дела штампана последњих десетак година. На пример: Марта Нусбаум (Martha Nussbaum), Сара Стридсберг (Sara Stridsberg), Лорин Вајсбергер (Lauren Weisberger), Ханс Магнус Енценсбергер (Hans Magnus Enzensberger),

${ }^{5}$ И у Речнику Бебкок (енгл. Babcock, стр. 10), Бебингтон (Babington, 10), Динсдејл (Dinsdale, боље него Динздејл, 37), Добсон (Dobson, 38), Фишборн (Fishbourne, 47), Гинсберг (Ginsberg, боље него Гинзберг, 54), ?! Хорнсби (Hornsby, боље него Хорнзбри, 64), Џусбери (Jewsbury, боље него Цузбери, 71), Ленсбери (Lansbury, боље него Лензбери, 78), али Бризбен (Brisbane, 18), Дезборо (Desborough, боље него Десборо, 36), Незбит (Nesbit, боље него Несбит, 100), Озборн (Osborn/Osborne/Osbourn/Osbourne, боље него Осборн, 104) итд.

${ }^{6}$ Друго је питање да ли је та традиција супротстављена начелима српске правописне норме или није. 
Андреас Ешбах (Andreas Eschbach), Роберт Динсдејл (Robert Dinsdale), Jу Несбе (Ju Nesbø), Јевгениј Водолазкин (Евгений Водолазкин), Николај Глазков (рус. Николай Иванович Глазков). Поред тога, са извршеном алтернацијом по звучности ту су (опет Британци, Немци, Руси, Пољаци) Марк Елзберг (Marc Elsberg), Димитриј Мерешковски (Дмитрий Мережковский), Гжегож Каздепке (Grzegorz Kasdepke), Ирина Жерепкина (Ирина Жеребкина).

5. У самим делима такође је низ примера у којима није дошло до алтернација по звучности. На пример, у делу А. Деблина Берлин Александерплаи из немачког језика попут: Вилмерсдорф (Деблин, 2017: 45), Рансдорф (45), Шлосброј (179), Адмиралсберг (335), Кенингсберг (438) или код Гинтера Граса у Псећим годинама као што су: Пробст (Грас, 2014: 133), Штрисбах (145), Кенигсберг (145), Обказ (255), Будцински (521), Кребс (453), Добслаф (195), Абст (266), Леобшиц (451), Котбус (454), Бисдорф (489), Нордхоф (544), Зубкац (691).

6. У новинским текстовима у оквиру истог текста или у истим новинама такође се могу наћи оба решења - са алтернацијом по звучности и без ње:

а) Називи градова

- Флензбург/Фленсбург (град у Немачкој, нем. Flensburg)

Др Басара је тренутно директор интерне клинике која се налази у немачком граду Флензбург (Блиц, 23. 8. 2019). Од пре 9 година сам на челу интерне медицине у Фленсбургу (Блиц, 23. 8. 2019).

- Аугсбург/Аугзбург (град у Немачкој, нем. Augsburg)

Евакуисане су већнице у Аугсбургу, Кајзерслаутерну, Емницу, Гетингену, Нојнкирхену и Рендсбургу (Блиц, 26. 3. 2019). Качар спреман да напусти Аугзбург (Блиц, 23. 2. 2018).

- Рендзбург (нем. Rendsburg) и Фленсбург (нем. Flensburg)

Немачка железничка компанија „Дојче бан” саопштила је да је због несреће затворен део пруге између Рендзбурга и Овшлага. Воз је саобраћао на релацији Хамбург - Фленсбург (Блиц, 8. 5. 2019).

- Солзбери/Солсбери (град у Великој Британији, енгл. Salisbury)

Хакери групе „Анонимус” објавили су документа из којих се види да су сарадници пројекта Интегрити инишиатив" неколико година пре инцидента у Солсберију позивали да се руске дипломате протерају из Велике Британије (Политика, 6-7, 1. 2019, 2). У Солзберију су 4. марта 2018. отровани двоструки шпијун Сергеј Скрипаљ и његова ћерка Јулија (Политика, 6-7, 1. 2019, 2).

- Регензбург/Регенсбург (град у Немачкој, нем. Regensburg)

Четрдесет Рома са Косова, из Албаније и Македоније запосели су петог јула Катедралу у Регенсбургу (Блиц, 3. 8. 2016). У бази НАТО-а код Регензбурга одржана је војна вежба (Блиц, 23. 11. 2011). 
- Јоханезбург/Јоханесбург (град у Јужноафричкој Републици, енгл. Johannesburg)

Судар у Јоханесбургу (Блиц, 5. 10. 2018). Амерички председник Барак Обама поздравио се с бројним светским лидерима на комеморацији Нелсону Мандели у Јоханезбургу (Блиц, 10. 12. 2013).

\section{б) Лична имена}

\section{- Ентони Годфри/Готфри (енгл. Anthony Godfrey)}

У америчкој амбасади подсећају да је амбасадор Ентони Годфри недавно објаснио да је у стратешком интересу САД да се Србија развија (Политика, 30. 11. 2019, 1). Мада ме је појава новог америчког амбасадора Ентонија Готфрија пољулала у тој накани (Време, 30. 1. 2020).

- Данијел Ретклиф/Редклиф (енгл. Daniel Radcliff)

Глумац Данијел Ретклиф каже да је због најновијег остварења толико себе изгладњивао, да му је килажа сада испод 50 килограма (Блиц, 14. 9. 2016). Изгледа да глумцу Данијелу Редклифу није било довољно чаробног света вештица и чаробњака (Блиц, 19. 9. 2014).

\section{- Григориј Родченков/Ротченков (рус. Григорий Родченков)}

Да би овај закон - назван по узбуњивачу Григорију Родченкову, ступио на снагу, неопходно је да га одобри Сенат (Политика, 9. 12. 2019, 18). Тај исти Григориј Ротченков продавао је руским спортистима „медикаменте” (Вечерње новости, 15. 12. 2019).

- Сергеј Бупка/Бубка (укр. Сергій Бубка)

У „Дружба” арени у Доњецку Сергеј Бупка поставио је два од својих 18 светских дворанских рекорда у скоку мотком (В. новости, 11. 4. 2015). Први потпредседник Атлетског савеза Сергеј Бубка и директор Атлетског савеза Србије Слободан Бранковић данас су обишли радове на Атлетском центру у Ћуприји (Вечерње новости, 29. 11. 2019).

\section{- уриј Радченко/Ратченко (укр. Юрій Радченко)}

„Такви мотори су се до 2001. године производили у украјинској фабрици Јужмаш”, изјавио је шеф украјинске свемирске агенције Јуриј Радченко (Политика, 15. 8. 2017). „Такви мотори су се до 2001. године производили у украјинској фабрици Јужмаш”, изјавио је шеф украјинске свемирске агенције Јуриј Ратченко (РТС, 15. 8. 2017).

- Сергеј Прихотко/Приходко (рус. Сергей Эдуардович Приходько)

Србија и Русија преговарају о обнови флоте, изјавио је високи званичник руске владе Сергеј Прихотко (Вечерње новости, 19. 10. 2019). Податак да је Приходко био на јахти, објавила је Настја Рибка у књизи (Вечерње новости, 13. 2. 2018).

\section{- Николај Рижков/Ришков (рус. Николай Иванович Рыжков)}

Рижков и Примаков би хтели да сведоче (Блиц, 1. 3. 2002). Тадашњи премијер Николај Ришков имао је са председником Горбачовом велико разумевање за развој породичних компанија (Политика, 8. 8. 2010).

\section{- Лев Гудков/Гутков (рус. Лев Гудков)}

Шеф руског „Левада-Центра” за истраживање јавног мњења Лев Гудков каже за амерички лист да „претња нуклеарним ратом такође чини то да се на становништво лакше утиче" (Политика, 25. 10. 2016). Сазрело је време промена”, изјавио је директор „Левада центра Лев Гутков (Политика, 8. 11. 2012). 
- Сергеј Рјапков/Рибков/Рјапков (рус. Сергей Алексеевич Рябков)

Москва је у контакту са Сједињеним Америчким Државама, рекао је данас заменик руског министра спољних послова Сергеј Рибков (Блиц, 14. 4. 2018). Заменик руског министра спољних послова Сергеј Рјабков изјавио је да Русија није спремна за размену Пола Велана (Политика, 6-7, 1. 2019, 2). Одређене снаге у САД не желе да Москва докаже да су оптужбе из Вашингтона у вези са ракетом 9М729 погрешне, изјавио је заменик руског министра спољних послова Сергеј Рјапков (РТС, 23. 01. 2019).

- Радко/Ратко Влајков (буг. Радко Влайков)

Амбасадор Бугарске у Србији Радко Влајков са супругом Јоаном организовао је пријем у хотелу „Метропол” (Политика, 4. 3. 2020, 16). Србија и Бугарска имају пријатељске односе, оценили су данас министар Зоран Ђорђевић и амбасадор Бугарске у Србији Ратко Влајков (Блиц, 14. 07. 2017).

Посебно су интересантни примери где у оквиру једног текста или чак имена аутора и наслова књиге имамо и неалтерниране и алтерниране сугласнике по звучности. На пример:

- Јевгениј Водолазкин (рус. Евгений Германович Водолазкин); наслов дела Бризбејн (енгл. Brisbane)

- Jy Несбе (норв. Јо Nesbø); наслов Магбет (енгл. Macbeth)

\section{4. ЗАКЉУЧАК}

1. У анализи примера из праксе који представљају правописне изузетке од алтернација по звучности све време се наметало питање да ли се они морају раздвојити по језицима - превасходно на оне из руског, енглеског и немачког језика (мада су ту они из пољског, украјинског и др.). Мишљења смо да то није потребно, те да се у адаптацији ономастике, али и опште лексике из свих овде поменутих језика поведе рачуна пре свега о томе да ли би једна алтернација по звучности довела до друге алтернације по звучности (нпр. Питсбург $>$ Питзбург > Пидзбург), те да ли постоје уобичајена ограничења (не само код ове алтернације, већ и код осталих) да до ње не дође (нпр. једносложним речима попут Џобс, а не Џолс).

2. Други разлог јесте традиција, тј. устаљеност једног решења чијом би се заменом проузроковала евентуална дилема. Оба решења захтевају и додатна појашњења. Адаптација презимена Хандке, на пример, није укључила и алтернацију по звучности, што јесте у складу с актуелном нормом, јер сонант $H$ нема безвучног парњака, те бисмо опет имали додир сонанта и безвучног сугласника (после алтернације: Хандке > Хантке). Али, да ли у пракси имамо таква решења, односно ситуације у којима су у додиру сонант (сви звучни) и безвучни сугласник, можда у општој лексици, али и ономастици? Наравно, имамо их. На пример на првом месту панталоне, пантомима, пантократија и сл., или Данте. Дакле, ништа спорно. Други аргумент који би могао овде 
бити примењен био би постојање презимена Хантке у немачком језику. А да ли је то уопште важно? Можда у свету постоји више Хандкеа и можда се многи зову и Петер.

3. Коначно, и трећи аргумент - традиција/устаљеност - овде је доведен у питање, тј. актуелна пракса га је довела у питање у више примера, а ми подсећамо, да опет останемо код презимена писаца, на Рушдија/Руждија и Гинзберга/Гинсберга. Наравно, не залажемо се за својеврсну флексибилност у пракси (нпр. оба решења), већ сматрамо да би кориговање традиције било оправдано ако би оно довело до усклађивања са нормом, тим пре што се правила о изузецима од алтернација по звучности нису у већој мери (ако изузмемо Белићево решење за алтернације $\partial: m$ испред $c$ и $u$ - забележено само у дублету Охридско/Охритско језеро, в. Белић 1923: 235 и назива Дбилиси, в. Белић 1930: 114, што није заживело у пракси) мењала кроз нормативистичку историју.

4. Оно о чему бисмо морали да поведемо рачуна јесу у ствари примери попут презимена Зубчић, које нам долази из хрватског језика, а које бисмо третирали као презиме Кадчић (П2010: 38) Наиме, алтернацију по звучности не бисмо спроводили у адаптацији примера из језика који у својој норми имају алтернацију по звучности. Тако остајемо доследни устаљеној норми по којој не алтернирају звучни и безвучни сугласници у примерима Eдхем, Mидхат (П2010: 37), па тако и Зубчић и сл. Постојање решења у којима је до алтернација по звучности дошло, па се то као аргумент узима за изостанак алтернације по звучности у овим примерима, секундарно је у нашој норми, јер је већ узето у обзир у, на пример у хрватској стандардизацији (нпр. Зубчевић, Фабковић у Бабић/Могуш 2011: 35).

5. У раду смо навели властито име Радко као словеначко и као бугарско име (женско име Радка, презиме Радков). Пошто је реч о словенским језицима попут руског који немају алтернацију по звучности у писању, до ње би дошло у нашој адаптацији датог имена (сетимо се бугарског презимена Разиветанов које је још у Правопису из 1960. прилагођено у Расиветанов, стр. 162). То не значи посрбљавање страног имена попут Михаил > Михаило (Михајло), Петер > Петар или у случају словеначких презимена попут Полич $>$ Полић, већ примену фонетског (фонолошког) правописа.

6. Дакле, предлог правилаิ за изостајање алтернације по звучности могао би да изгледа овако:

До алтернације не долази:

1) Ако реч почиње самогласником/самогласницима иза којег/којих су у додиру два по звучности неједнака сугласника, нпр. Аnдајк (презиме), Обски залив, Оукбриц. 
2) У једносложним речима са два завршна сугласника различите звучности (Џобс, Кабс, као плебс).

3) У речима са два иницијална сугласника различите звучности (Тбилиси).

4) У речима у којима би алтернација по звучности довела до даљих алтернација, нпр. Питсбург - да би се избегла следећа алтернација по звучности (*Питсбург > Питзбург > Пидзбург) или губљење сугласника (*Гудиов $>$ Гутиов $>$ Гуциов).

Напомена: На тај начин избегло би се и добијање сугласничких група које нису својствене српском језику. Правопис из 2010. наводи четири такве групе -кск-, -иск-, -ти-, -тч- и примере Мусоргски, Рјажски, Гудиов, Дјадченко. Овде смо споменули губљење сугласника, које би се, евидентно могло реализовати у примерима Рјажски (Рјашски, попут Праг+ -ски > пражски > прашски > прашки), Гудиов (Гутиов $>$ Гуичов, попут отаи $>$ отия $>>$ оца) и Дјадченко (Дјатченко > Дјаченко, попут отаи $>$ отие $>$ отче $>$ оче), мада се од ове четири споменуте групе две сигурно јављају у српском језику и то нпр. код глагола отчепити и отиепити.

5) У примерима код којих постоји рашчлањен изговор у коме и нема асимилације по звучности, са секундарном наглашеношћу или чак двојним акцентом, попут Мекбрајд, Вестбрук, Јангие и сл.

У свим другим случајевима до алтернације по звучности ће доћи, дакле Готфри, Водоласкин, Вајзбергер, Незбе, Розберг, Регензбург, Штризбах и сл.

7. Важно је рећи још и то да се у општој лексици један број изузетака од ове алтернације, али не само ње, објашњава тиме да је реч о новијим позајмљеницама. Међу њима, видели смо, традиционално се наводе именице гангстер или терминолошки маркиране јурисдикција и сл. и оне у којима се јасно и у (из)говору осећа двочланост (неке имају и два акцента) и које су често и сложенице попут фејсбук. На примеру једне, позајмљенице гангстер, Р. Симић чак наводи да је то ипак „неконтролисани уступак етимологији” (Симић 1991: 338) уместо прилагођеног (са алтернацијом по звучности) ганкстер. Наравно, и међу њима има оних које се ипак не могу сврстати у исту групу, јер је евидентно да је у некима немогућа алтернација по звучности, као у случају именице плебс, из истих разлога као и у домаћим речима (нпр. изведенице убски, са творбеном основом именицом Уб).

8. На крају, опет не по значају, испитивање да ли је и у којој мери оправдано да до алтернације по звучности не дође, не може мимоићи ни остале алтернације и њихове изузетке. Некако у вези са алтернацијом по звучности јесте алтернација по месту и начину творбе - поготово у случају ономастике (Истанбул, Бранденбург и сл.) и поново су у питању већ споменута два аспекта - прозодија и етимологија. 


\section{ИЗВОРИ}

\section{Блиц}

1. 3. 2002: https://www.blic.rs/vesti/hronika/rizkov-i-primakov-bi-zeleli-da-svedoce/lrevwn6, посећено 15. 2. 2020.

23. 11. 2011: https://www.blic.rs/vesti/politika/nemacki-vojnici-glumili-srbe-na-barikadama-na-severu-kosova/p3s41ns, посећено 21. 11. 2018.

10. 12. 2013: https://www.blic.rs/vesti/svet/pogledajte-istorijski-gest-obama-se-rukovao-s-raulom-kastrom/7zex9ee, посећено 21. 11. 2018.

19. 9. 2014: https://www.blic.rs/zabava/vesti/avanture-harija-potera-u-amsterdamu-glumac-uzivao-u-marihuani/g7v3xx4, посећено 25. 2. 2020.

3. 8. 2016: https://www.blic.rs/vesti/svet/romi-sa-zapadnog-balkana-zauzeli-katedralu-u-nemackoj-i-porucuju-necete-nas/004dx77, посећено 21. 11. 2018.

14. 9. 2016: https://www.blic.rs/zabava/vesti/ne-lici-na-sebe-zbog-ulogesvetskiglumac-ima-manje-od-50-kilograma/jmkkqjc, посећено 25. 2. 2020.

14. 7. 2017: https://www.blic.rs/vesti/drustvo/djordevic-razmena-iskustva-sa-bugarskom-u-oblasti-rada/7w5ckfp, посећено 17. 8. 2020.

23. 2. 2018: https://sport.blic.rs/fudbal/evropski-fudbal/pokusao-opet-ali-ne-ide-kacar-spreman-da-napusti-augzburg/vmp5g01, посећено 4. 5. 2020.

14. 4. 2018: https://www.blic.rs/vesti/svet/rusija-omeksala-nakon-americkog-bombardovanja-sirije-sad-smo-spremni-na-saradnju-sa/r0c7dmz, посећено 15. 1. 2019.

5. 10. 2018: https://www.blic.rs/vesti/svet/sudar-u-johanesburgu-vise-od-300-povredenih-kad-se-lokomotiva-zakucala-u-voz-koji-je/m9nhylv, посећено 21. 11. 2018.

26. 3. 2019: https://www.blic.rs/vesti/svet/evakuisane-gradske-vecnice-u-nemackoj-zbog-dojave-o-bombama-foto/5rvddkz, посећено 4. 5. 2020.

8. 5. 2019: https://www.blic.rs/vesti/svet/nesreca-u-nemackoj-u-sudaru-kamiona-i-voza-povredeno-najmanje-20-ljudi/kenvesf, посећено 4. 5. 2020 .

23. 8. 2019: https://www.blic.rs/ponosni-na-srbiju/kod-mene-ljudi-ne-umiru-lekarka-iz-beograda-je-do-sada-uradila-preko-2000/z04zsed, посећено 14. 2. 2020. 


\section{Вечерње новости}

11. 4. 2015: https://www.novosti.rs/vesti/sport.297.html:542952-Bupka-Srbi-ce-zasijati-u-Riju, посећено 16. 2. 2020.

13. 2. 2018: http://www.novosti.rs/vesti/planeta.299.html:711556-SKANDAL-RIBICA-TRESE-RUSIJU-Seks-i-politika-na-jahti-oligarha-FOTO, посећено 26. 10. 2019.

19. 10. 2019: http://www.novosti.rs/vesti/naslovna/drustvo/aktuelno.290. html:825170-RUSI-HOCE-DA-GRADE-NUKLEARKU-U-SRBIJI-Dok-Er-Srbija-pregovara-o-kupovini-suhoja-SSJ-100-stigao-i-nov-predlog, посећено 26. 10. 2019.

29. 11. 2019: https://www.novosti.rs/vesti/sport.297.html:832515-Bubka-u-Cupriji-Atletski-centar-ce-biti-fantastican-FOTOVIDEO, посећено 16. 2. 2020.

15. 12. 2019: https://www.novosti.rs/vesti/sport.297.html:836118-Sport-oruzje-protiv-Rusije-Iskljucenje-ruskih-sportista-iz-svetskih-takmicenja-deo-hladnog-rata-velikih-sila, посећено 15. 7. 2020.

Водолазкин 2019: J. Водолазкин, Бризбејн, Београд: Службени гласник.

\section{Време}

30. 1. 2020: https://www.vreme.com/cms/view.php?id=1749483, посећено 22. 2. 2020 .

Гинзберг 1983a: А. Гинзберг, Урлик ума, изабране песме, Београд: Дом омладине Београда.

Гинзберг 1983б: А. Гинзберг, Хидрогенски иубокс: изабране песме, Београд: Народна књига.

Грас 2014: Г. Грас, Псеће године, Београд: Лагуна.

Деблин 2017: А. Деблин, Берлин Александерплаи, Београд: Лагуна.

Керуак/Гинсберг 2016: Џ. Керуак, А. Гинсберг, Изабрана писма, Београд: Клио.

Несбе 2018: J. Несбе, Магбет, Београд: Лагуна, 2018. 


\section{Политика}

8. 8. 2010: http://www.politika.rs/sr/clanak/145262/Politika/Vise-zemalja-nudilo-mi-je-azil, посећено 15. 2. 2020.

8. 11. 2012: http://www.politika.rs/sr/clanak/239283/Muke-internet-opozicije, посећено 20. 2. 2020.

25. 10. 2016: http://www.politika.rs/sr/clanak/366473/Svet/Volstrit-dzurnal-Rusi-vezbaju-atomski-napad, посећено 20. 2. 2020.

15. 8. 2017: http://www.politika.rs/scc/clanak/387032/Свет/Кијев-Мотори-уракетама-Северне-Кореје-били-су-само-за-Русију, посећено 20. 2. 2020 .

6-7, 1. 2019, 2.

30. 11. 2019, 1.

9. 12. 2019,18 .

4. 3. 2020,16 .

20. 3. 2020: http://www.politika.rs/sr/clanak/450487/SZO-upozorava-da-i-mladi-mogu-da-stradaju-od-koronavirusa, посећено 5. 4. 2020.

\section{PTC}

15. 8. 2017: http://www.rts.rs/page/stories/sr/story/10/svet/2838543/kijev-motori-u-raketama-severne-koreje-bili-su-samo-za-rusiju.html, посећено 20. 2. 2020.

23. 1. 2019: http://www.rts.rs/page/stories/sr/story/10/svet/3395863/rjabkov-sad-ne-zeli-da-dokazemo-da-su-optuzbe-o-raketama-lazne. html, посећено 15. 2. 2020.

Ружди 2002: С. Ружди, Срамота, Београд: Народна књига - Алфа.

Ружди 2004: С. Ружди, Гримус, Београд: Политика - Народна књига.

Ружди 2007: С. Ружди, Кловн Шалимар, Београд: Народна књига - Алфа.

Ружди 2013: С. Ружди, Дец̧а поноћи, Београд: Дерета.

Ружди 2019: С. Ружди, Сатански стихови, Београд: Вулкан издаваштво.

Рушди 1989: С. Рушди, Деца поноћи, I-II, Београд: БИГЗ.

Рушди 1991: С. Рушди, Сатански стихови, Београд: Просвета. 


\section{ЛИТЕРАТУРА}

Бабић/Могуш 2011: С. Бабић, М. Могуш, Хрватски правопис, Загреб: Школска књига.

Белић 1923a: А. Белић, Правопис српскохрватског кьижевног језика, Београд: Издавачка књижарница Геце Кона.

Белић 1923б: А. Белић, О савременом правопису српскохрватског књижевног језика, Просветни гласник, бр. 4, април 1923, стр. 206-218.

Белић 1928/29: А. Белић, Поводом расправе: О писању руских имена у нашем народу, Јужнословенски филолог, VIII, 137-141.

Белић 1930: А. Белић, Правопис српскохрватског књижевног језика, Београд: Издавачка књижарница Геце Кона.

Белић 1950: А. Белић, Правопис српскохрватског кюижевног језика, Просвета, Београд.

Дешић 2015: М. Дешић, Правопис српског језика, Београд: Клет.

Маројевић 1988: Р. Маројевић, О транскрипцији руских антропонима и топонима у српскохрватском језику, Кюижевни језик, 17/2, 105-110.

Менац 1971/72: А. Менац, О писању руских имена, Језик, XIX, 4-5, 97-109.

Правописно упутство 1929: Правописно упутство за све основне, средюе и стручне школе Краљевине Срба, Хрвата и Словенацуа, Министарство просвете Краљевине Срба, Хрвата и Словенаца.

П60: Правопис српскохрватског - хрватскосрпског књижевног језика, Нови Сад - Загреб: Матица српска - Матица хрватска.

П93: М. Пешикан, Ј. Јерковић, М. Пижурица, Правопис српскога језика, Нови Сад: Матица српска.

П2010: М. Пешикан, Ј. Јерковић, М. Пижурица, Правопис српскога језика, Нови Сад: Матица српска.

Прћић 1998: Т. Прћић, Нови транскрипциони речник енглеских личних имена, Нови Сад: Прометеј.

Прћић 2004: Т. Прћић, Енглеско-српски речник географских имена, Нови Сад: Змај.

Симић 1991: Р. Симић, Српскохрватски правопис, Београд: Научна књига.

Симић и др. 1993: Р. Симић, Ж. Станојчић, Б. Остојић, Б. Ћорић, М. Ковачевић, Правопис српскога језика са речником, Никшић - Београд: „Унирекс" - „Штампа”. 
Симић 1998: Р. Симић (ред.), Правописни приручник српскога књижевног језика, Београд: Научно друштво за неговање и проучавање српског језика.

Симић 2016: Р. Симић, Српски правопис, Београд: Научно друштво за неговање српског језика, Јасен.

Стакић 2010: М. Стакић, Морфо(фо)нолошке теме, Београд: Друштво за српски језик и књижевност.

Стевановић 1986: М. Стевановић, Савремени српскохрватски језик, књ. 1, Београд: Научна књига.

Ћупић и др. 1996: Драго Ћупић, Егон Фекете, Богдан Терзић, Слово о језику - језички поучник, Нови Сад: Партенон.

Шипка 2011: М. Шипка, Стандарднојезичка преиспитиваға 3, Нови Сад: Прометеј.

\section{ORTHOGRAPHIC EXCEPTIONS FROM ALTERNATIONS BY SONORITY IN THE SAMPLE OF ONOMASTICS}

\section{Summary}

Orthographic exceptions from alternations by sonority are analyzed excerpted from the sample of adapted onomastics from foreign languages (mainly from English, Russian and German). This orthographic issue was analysed through the analysis of normative handbooks starting from orthography by Belic, published in 1923 and its subsequent editions, to editions by Matica Srpska and completing with the current one published in 2010, as well as the ones by Desic (2015) and by Simic (2016) normative handbooks. Examples are excerpted from newspaper pieces and translated works of literature.

Keywords: Serbian orthography, alternation by sonority, orthographic exceptions, adaptation of foreign vocabulary, onomastics. 